\title{
From Pandemic to New Normal: Portraying EFL Graduates' Metacognitive Strategy in Thesis Writing
}

\author{
Rizqiyyah 1 , Joko Nurkamto ${ }^{2}$, Dewi Rochsantiningsih 3 \\ DOI: 10.35445/alishlah.v13i2.500
}

\begin{abstract}
Article Info
Abstract

Keywords:

COVID-19;

EFL Graduates;

Metacognitive Strategy;

Thesis Writing

The recent paper aims to figure out how students apply their metacognitive strategies of thesis writing in the COVID-19 pandemic. This study employs an explanatory case study design with 13 English As a Foreign language (EFL) graduates of an Indonesian university involving in this study. Questionnaires and semi-structured interview methods were used for collecting information. The data were then qualitatively analyzed using Miles, Huberman, and Saldana interactive model. The findings indicate that individual differences and thesis supervisors' involvement stimulated varied metacognitive strategy use in thesis writing. The challenges, inefficient time management, supervision system, technological issues, and negative disruptive emotions were attributed to delayed thesis completion in the pandemic. It indicates that the metacognitive experience represented by negative psychological factors profoundly affects students' metacognitive strategies. Hence, promoting students' positive affective states are essential to achieve the expected writing outcomes.
\end{abstract}

\begin{abstract}
Abstrak
Penelitian ini bertujuan untuk mengetahui cara mahasiswa menerapkan strategi metakognitif untuk menyelesaikan masalah yang muncul selama penulisan tesis di masa pandemi. Penelitian ini menggunakan desain studi kasus eksplanatori dengan jumlah informan sebanyak 13 mahasiswa pascasarjana di salah satu Universitas di Indonesia. Kuesioner dan metode wawancara semi-terstruktur digunakan untuk mengumpulkan informasi.

Data tersebut kemudian dianalisis secara kualitatif dengan model interaktif Miles, Huberman, dan Saldana. Temuan menunjukkan bahwa perbedaan individu dan keterlibatan dosen pembimbing mempengaruhi variasi penggunaan strategi metakognitif dalam penulisan tesis. Manajemen waktu dan sistem supervisi yang tidak efisien, permasalahan teknologi, and faktor psikologis merupakan variabel pemicu tertundanya penyelesain penulisan tesis selama pandemi. Pengalaman metakognitif yang direpresentasikan oleh faktor psikologis negatif tersebut memberikan pengaruh yang sangat besar terhadap strategi metakognitif yang digunakan. Oleh karena itu, membangun emosi positif siswa penting dilakukan agar mereka bisa mencapai hasil menulis yang diharapkan.
\end{abstract}

Kata kunci:

COVID-19;

Mahasiswa

Pascasarjana;

Strategi Metakognitif;

\footnotetext{
${ }_{1}$ Universitas Sebelas Maret, Indonesia Email: rizqiyyah@student.uns.ac.id ${ }_{2}$ Universitas Sebelas Maret, Indonesia Email: jokonurkamto@staff.uns.ac.id ${ }_{3}$ Universitas Sebelas Maret, Indonesia Email: dewi_roch@hotmail.com
} 


\section{INTRODUCTION}

Writing is a complex process demanding for English As a Foreign language (EFL) students and even for native speakers of English. As cited in Cer (2019), Gozukucuk (2016) stated that writers transfer, modify, arrange, and assess their thoughts and feelings. Hence, they are supposed to reflect on their knowledge and practices. This reflective process necessitates critical thinking, which associates with problem-solving (Nhat et al., 2018) and metacognition (Farahian \& Avarzamani, 2018; Murtadho, 2021; Soberg, 2018). De Silva and Graham (2015) claimed that students' knowledge of metacognition affects their writing skills through the act of constructing a plan, monitoring, and assessing practice. It indicates that students' metacognitive strategies influence their writing accomplishments.

Writing skill helps students ensure their future success in academic life (Cer, 2019). Thesis writing is a step that students, typically in the Indonesian context, must pass through to study completion. However, when the Covid-19 virus attacks the human body worldwide starting in 2020 up to new normal post-pandemic, the number of students completing the graduate program within four semesters, especially in an English department of a university in Indonesia, dropped by nearly $70 \%$ from the preceding years. Consequently, students are likely to take longer to graduate (Aucejo et al., 2020; Indrawati, 2020). Due to this fact, students need to think more critically to tackle all the challenges they may experience during the writing process in lockdown, large-scale social restriction, and new normal life. The role of metacognition has never been this important these days.

Previous studies have elaborated that teachers mainly focused more on the product-oriented approach than on the process-oriented approach to teach writing during the pandemic. The use of online writing tools (Handayani \& Handayani, 2020), graphic organizers (Styati \& Irawati, 2020), and authentic materials (Lestari Setyowati, 2020) as writing strategies are promising to the amelioration of students' writing skills. However, they were mainly used for boosting the scores only. How students executed the writing process was a bit neglected, whereas the act of evaluating and revising is crucial in improving the writing quality. Kasper (1997) and Victory (1999), as cited in Xiao, 2007, urged teachers to assist students to be aware of their writing processes and strategies. This awareness is called as the metacognition of writing.

Metacognition is the mental image of one's cognition (Hacker, 2009) and originates from psycholinguistics. It contributes significantly to writing since students are supposed to reflect on their knowledge and practices by monitoring and evaluating the process (Tinberg, 2015), drafting, revising, and checking the draft (Tosuncuoglu \& Kirmizi, 2019). The writing above process is articulated as a metacognitive strategy (Wenden, 1998). The metacognitive strategy includes three phases: planning and drafting, monitoring, and evaluating and revising (Farahian \& Avarzamani, 2018). At the planning stage, writers identify aims, audience, ideas, strategies (Goctu, 2017, pp.86), determine lofty goals of writing and identify sources (Teng, 2019), did semantic mapping for brainstorming ideas (Wei, Chen, \& Adawu, 2014); make time allotment and construct a draft (Ong \& Zhang, 2013; Qin \& Zhang, 2019). The second stage of metacognitive strategy in writing is monitoring the progress. Monitoring is a process of evaluating learning (Schraw \& Dennison, 1994). Writers make sure to check the progress on both 'global' and 'local' features (Goctu, 2017, pp.86). The preceding refers to content and organization, while the latter concerns grammar and mechanics. High proficiency students typically focused more on reviewing the writing content, organization, and grammar (Qin \& Zhang, 2019). Maftoon, Birjandi, and Farahian (2014) mentioned some additional strategies from the findings that affected students' regulation of cognition, which were labeled as online strategies. The strategies included time and strategies adjustments, avoidance strategy, and self-regulation from distraction (Maftoon et al., 2014). Finally, evaluating and revising is the last stage of metacognitive strategies in writing. Writers could perhaps notice the strength and weaknesses of their writing, which is suitable for future development. They also review the global and local writing features strategies to accomplish the expected outcomes (Goctu, 2017). They will 
assess whether the strategies used ran well or not and anticipate things that might negatively affect their writing performance.

Turning now to related literature, studies on how EFL students employed their metacognitive strategies in writing are flourishing (Cer, 2019; Qin \& Zhang, 2019; Farahian \& Avarzamani, 2018). Cer (2019) employed a mix-method study emphasizing metacognitive strategies to enhance students' self-efficacy and writing skills. The study revealed that teachers should assist learners in planning, monitoring, and evaluating the draft before asking them to compose an essay in the teaching and learning process. Freewriting composition performed by learners in the control group did not help them significantly developed their writing skills. Besides, Qin and Zhang (2019) explored the extent to which students' metacognitive strategy affected their writing skills in multimedia EFL teaching and learning. The findings show that students with a strong awareness of metacognition had a clear goal before accomplishing the composition, set the aim of writing, made time allotment, and constructed the draft. They made some modifications to ensure that the aim was achieved and evaluated to assess whether the strategies ran well.

Despite abundant studies on metacognition in writing, there has been little discussion on how EFL students perform their metacognitive strategies, particularly at the post-graduate level. This study attempts to select EFL graduates as informants because they have fully developed their metacognitive ability (Kelly, 2018; Weil et al., 2013), metacognitive strategies (Sala-Bubaré \& Castelló, 2018; Weil et al., 2013), and metacognitive awareness in all aspects (Panda, 2017). Thus, how students with high metacognition address writing challenges during the covid19 outbreak is an intriguing topic to discuss. This study aimed to explore how EFL graduates implemented their metacognitive strategies, investigated the challenges, and overcame the problems during the pandemic's thesis writing.

\section{METHODS}

This study explored in-depth discussion on how and why students performed specific metacognitive strategies-based writing at the surface and profound level. Thus, a descriptive case study was carried out with 13 EFL graduates of an Indonesian university as participants. They were students in the fourth semester of the study, engaging in the thesis writing course. One out of 13 has taken the thesis examination in the fourth semester, whereas the rest were still working on it. Two research questions will be answered using two distinct data collection: questionnaires and semistructured interviews. The information from the questionnaires complemented the interview findings. The researchers adapted Farahian and Avarzamani's (2018) questionnaire, MAWQ (Metacognitive Awareness Writing Questionnaire), by adding one open-ended question, "to what extent does the pandemic affect your thesis writing?" and Farahian's (2015) interview guideline on the regulation of cognition.

Regarding the data collection procedure, we first asked for participants' involvement by informing the project aims. 13 participants managed to take part in this study and filled in the questionnaires online. Afterward, we gained a deeper understanding of the topic by interviewing them by utilizing video-conferencing tools and Whatsapp. Out of 13 informants, four of them voluntarily participated in the interview session. After collecting the data, we used Miles, Huberman, and Saldana's (2014) theory for data analysis: data condensation, data collection, data display, and conclusion drawing.

\section{FINDINGS AND DISCUSSION}

This paper section examines the questionnaires' results related to the informants' metacognitive strategies during the writing process and investigates the pandemic's effect on thesis writing through interviews. Tables 1-3 represent the proportion of informants employing specific metacognitive strategies during planning and drafting, monitoring, regulating general online strategies, and evaluating and revising their thesis writing in a pandemic situation. It is seen that 
among all the writing stages, the informants struggled the most at generating online strategies that affected their regulation of the writing process. See further explanation below.

\section{The planning and drafting stage}

Table 1. Students metacognitive strategies during the planning and drafting stage

\begin{tabular}{|c|c|c|c|c|}
\hline Components & Sub-Components & Indicators & Yes & No \\
\hline Metacognitive & Planning and & 1. Outlining & 12 & 1 \\
\hline \multirow[t]{5}{*}{ Strategies } & drafting & 2. Drafting & 11 & 2 \\
\hline & & 3. Language resources & 7 & 6 \\
\hline & & 4. Goal Setting & 11 & 2 \\
\hline & & 5. Set specific audience & 9 & 4 \\
\hline & & 6. Reading preparation & 13 & O \\
\hline
\end{tabular}

Table 1 represents the proportion of informants who employed specific metacognitive strategies during the planning and drafting stage in thesis writing. All informants reported that they shared the same strategy to plan the thesis by diving into the literature to find the research topic sources. A small minority of the subjects, $10 \%$, reported that they did not generate outlines for writing which means that the majority took more planning sessions by brainstorming ideas into either lists or mind maps. Besides, less than $85 \%$ of the subjects have reportedly applied drafting techniques to elaborate the ideas into sentences. Regarding language resources, just over half of the informants (53\%) emphasized linguistic resources. Furthermore, a vast majority, $84 \%$, stated that they set the aim of writing. Finally, 9 out of 13 informants visualized that thesis supervisors, lecturers, and classmates were their target audiences.

Regarding goal setting, the interview results indicate that they share the same goal: to write a thesis to earn the master's degree and achieve clarity in writing. However, they also stated that diverse writing aims are influenced by individual differences such as educational background and career goals. An informant said, "I write the thesis for self-reflection as I am a teacher candidate."

In terms of setting a specific audience, the result of the questionnaires illustrates that 9 out of 13 informants visualized who the audiences were before they started writing. All graduates stated that their target audiences were their thesis supervisors, lecturers, and classmates. The result of the interviews also showed that all informants managed to find sources by reading a lot. It indicates that the informants were aware that reading is a crucial precursor to writing. This value is typical of previous findings claiming that reading and writing skills are interconnected (Fitzgerald \& Shanahan, 2000). Reading helps authors brainstorm ideas (Graham et al., 2018). The informants explained:

"My research interest has been centering on autonomous learning since the first semester of my master study when I had academic writing projects."

\section{"I found myself a slow reader that I need to read a journal article two or three times to comprehend what the author says."}

"I read the articles from reputable journals. I checked Scimago's journal rank to know how good the journal was and accessed Beall's list site to avoid the probability of utilizing predatory journals as the references".

The excerpt above has strengthened our confidence that the informant was metacognitively aware that familiarity played an essential role in the writing process. The informants also realized their strength and weaknesses as a reader. They could measure the quality of their reading skills concerning the rate of reading speeds. Thus, they addressed the challenge by applying a repetitive reading strategy. An informant could also identify suitable sources of reading material, which means that she knows how high-quality references differ from low ones. On top of those facts, all informants have indicated that they applied various reading strategies to adjust to individual differences. 
Furthermore, this study provides insight into how the informants brainstormed writing ideas and put them into complete sentences/ paragraphs. The interview result revealed that the mind map, the lists, the scratch, and the note-taking technique utilized the outlining and drafting tool to organize essential ideas. At last, it is crucial also to note that this study reveals the finding related to the time allotted by the informants in planning to write the thesis. Those interviewed mentioned that they made a timeline visualization to ensure that they finish writing on the scheduled time.

\section{Monitoring}

Table 2. Students Metacognitive strategies in the monitoring stage

\begin{tabular}{lllrr}
\hline Components & Sub-Components & Indicators & Yes & No \\
\hline Metacognitive & Monitoring & Global and Local & 12 & 1 \\
Strategy & General Online & 1. Time adjustment & 2 & 11 \\
& Strategies & 2. Avoidance & 6 & 7 \\
& & 3. Dictionary use & 13 & 0 \\
& 4. Get help from & 10 & 3 \\
& & others & & 10 \\
& 5. Self-regulation & 3 & \\
& from distraction & & \\
\hline
\end{tabular}

Table 2 illustrates that a small proportion (15\%) explained that they could effectively manage the allocated time to write. Besides, a significant majority of the informants (77\%) also informed that they could not successfully control their attention, so that they ended up easily sidetracked during the composting process. In terms of asking for help, all informants consulted with resources such as online dictionaries or webs. A significant proportion of them (77\%) reported that they managed to ask for help from classmates and thesis supervisors.

The interview results indicated that the informants monitored their writing progress by concentrating on global and local features. Cohesion, coherence, clarity, and content were the areas where they were concerned the most. Little did they pay attention to local features such as grammar, spelling, and punctuation. The study findings substantiate previous findings stating that while writing, the students concentrated on the content and the language features (Goctu, 2017). However, they spent less time checking the textual features of their writing, such as grammar, punctuation, and mechanics, than on the global features such as content, text organization, and coherence (Qin \& Zhang, 2019).

The results from the interview illustrate that the informants got distracted easily and eventually could not effectively budget the time due to technical problems, psychological and social factors. They stated:

"I spent much time doing household chores at home."

"This pandemic influences my thesis writing . I get more laziness and less motivation".

"When I presented the thesis plan in group-supervision session using Google Meet, the connection was interrupted for about 15 minutes, and my laptop freezes. Thus, some parts of my plan had not been discussed with my supervisor".

"I could not finish writing based on the schedule as I got easily distracted by neighbors' kids who frequently visited me."

Furthermore, when the informants were unfamiliar with a specific structure or vocabulary item, they used an avoidance strategy to let the ideas flow smoothly. However, when they got stuck, they asked for help diversely. They stated:

"My thesis supervisors provided both offline and online feedback. Nevertheless, I prefer asking my friends who work in the same area as me if I experienced difficulties confirming directly with the supervisors. I invited my friends to have peer feedback using zoom conference. We took a turn presenting our works and provided feedbacks for better writing quality. Later on, I resubmit the edited version to the supervisors". 
"I asked some friends to check/read my writing to get their feedback to fill the writing holes. I sent them the file through Whatsapp and received the highlighted feedback version".

The findings are consistent with previous studies stating that students sought help from webs, classmates, and teachers (Maftoon et al., 2014; Ramadhanti et al., 2019). The finding highlighted that discussing with classmates brought a significant effect to improve the quality of writing. However, it contradicts what Teng and Huang (2018) have found in their study with Chinese students. Peer feedback's role receives a more positive attitude in the Indonesian context than in the Chinese context. Nevertheless, the finding still needs to be interpreted with caution because the participants in this study have different education levels in Teng \& Huang's study. In addition, the interview result indicated the significance of online communication media such as Zoom, Google Meet, and Whatsapp facilitating online discussion to achieve better thesis writing outcomes. Those aidful resources were utilized as document and information sharing. The finding corroborates previous studies that online writing tools support interaction between students and lecturers during pandemics (Handayani \& Handayani, 2020; Wajdi et al., 2020).

\section{Evaluating and revising}

Table 3. Students Metacognitive strategies in the evaluating and revising stage

\begin{tabular}{|c|c|c|c|c|}
\hline \multirow[t]{5}{*}{ Components } & Sub-Components & Indicators & Yes & No \\
\hline & Evaluation & 1. Self-assessment & & \\
\hline & Revision & $\begin{array}{l}\text { Organization \& Content } \\
\text { 2. } \frac{\text { Self-reflection for future }}{\text { development }}\end{array}$ & 12 & 1 \\
\hline & & Quality measurement & 11 & 2 \\
\hline & & Expectation & 8 & 5 \\
\hline
\end{tabular}

Regarding the evaluation and revision process, it is seen from table 3 that well above four-fifths (92\%) of them automatically focused on the text organization and content. They checked whether the content and text organization fits the original plan. They also involved their classmates and supervisors in getting feedback. What is more, the informants conducted self-reflection for future development by measuring how well they have done and check whether their writing has met the expectation. A substantial proportion (85\%) commented that they could calculate the quality of their writing. The questionnaire result is in line with the findings from the interview. The informants stated:

"I think my thesis is just mediocre. I do not know what the strengths of my writing are, and I'm sure that there are plenty of mistakes in my writing".

"I need to learn how to search for relevant references and transfer my ideas so that they are well delivered. Consequently, I need to devote more times to read as much as I can".

"I have tried my best to revise the thesis. However, I'm still not sure whether it meets my supervisors' expectations.

The findings indicate that all informants evaluated and revised the text thoughtfully to meet their thesis supervisor's expectations. It corroborates with results from the previous study (Maftoon et al., 2014), stating that students reread the text and revised their final text to satisfy teachers. Regarding self-reflection for better writing outcomes, the interview results indicate that the informants underestimated their writing skills. Being self-aware of the weaknesses, however, brings a positive effect on writing development. The informants could mention some strategies which are applicable for better outcomes in future writing. 


\section{The obstacles during the writing process}

The most striking result to emerge from the data is the open-ended question discussing to what extent the pandemic has affected the writing process, as shown in table 4 . Having coded the data, the results of the questionnaires indicated that four aspects trigger problems in writing thesis during a pandemic: inefficient supervision sessions, lack of motivation, procrastination habit, and imposter syndrome.

\section{Table 4. Challenges in thesis writing during the COVID-19 pandemic}

\begin{tabular}{ll}
\hline Question & To what extent does the pandemic affect the thesis writing? \\
\hline Responses & "The biggest influence is coming from myself that the more I have free time, the more \\
laziness I have. It makes me think that I still have another day to write my thesis proposal. \\
That is all." \\
"This pandemic takes my motivation away.. I can't focus on writing my proposal since there \\
come many worries in mind... I cannot go to my favorite place that gives me the comfort to \\
start writing nor meeting people to ease my confusions even though we can discuss through \\
social media or by a phone call..." \\
It's not easy to meet the supervisors and get the real source of the writing in the library. \\
"Pandemic affects on my consultation time. I need to wait for my supervisor to accept my \\
writing." \\
"The delay in consultation time led to uncertainty, and it made me less motivated." \\
"It affects me just to feel slow down is okay, which makes my writing has no progress. But, \\
I'm aware it's my problem (idea \& reading time problem), not because of the pandemic. \\
Even without the pandemic, I expected that my writing would still be problematic."
\end{tabular}

The researchers developed substantive theories from the findings of the current study as follows: (1) Thesis supervisors' involvement is crucial in all stages of writing; (2) Individual differences affect metacognitive strategies in writing during a pandemic; (3) Time management and supervision session were believed to be the central issue during writing process due to writers' lack of motivation, procrastination habit, and imposter syndromes.

\section{The role of thesis supervisors}

The role of thesis supervisors is crucial at all stages of thesis writing. Before the global pandemic, regular one-on-one meetings were scheduled more frequently than online supervision due to its practicability that provided rapid exchanging information access. The supervisors provided direct feedback and had a two-way discussion with the informants. While amid pandemic, email and Whatsapp are offline communication platforms frequently used during consultation. However, its usage led to the indirect and nonreciprocating communication between thesis supervisors and students, affecting the writing progress. The informants also expressed that some supervisors organized regular weekly meetings while the others scheduled a meeting when the supervisee made an appointment. Thus, the supervision style was influenced by thesis supervisors' individual preferences (Salgado, 2015). An informant explained, "our supervisor initiated a Whatsapp group to track the development of thesis writing. We have group supervision twice a week via Google Meet to present the research plan using Powerpoint". The other informant elaborated, "the online supervision session usually took two hours. Our supervisor did not spoon-feed us by giving the solution, yet he encouraged us to have group feedback to solve the problem".

The interview result indicated that thesis supervisors provided guidance for the research plan and helped students structure the thesis organization. It corroborates Attard's (2018) finding asserting that discussing the research with the supervisors would guide the students to determine whether the plan was feasible. The students, later on, modified the plan after getting the feedback. Concerning plan modification, Farahian and Avarzamani (2018) stated in their study, there have been contradictive findings in previous research stating that writers followed their plans without changing (Maftoon et al., 2014) while others did not stay with the original intention (Teng, 2019). This research finding adds empirical data to support the latter idea due to the intervention from 
thesis supervisors. While at the monitoring stage, the supervisors provided metalinguistic feedbacks triggering students' critical thinking. It substantiates previous findings that supervisors guided and facilitated students' 'total development' (Winston et al., 1984) by 'providing technical and intellectual support' (Mhunpiew, 2013). Finally, in the reflection stage, they acted as a mentor by assessing students writing performance and gave insight for better outcomes.

\section{Individual differences and metacognitive strategies}

Let us now look at the second substantive theory, which confirms findings from previous literature stating that metacognitive strategies in writing are very much influenced by students' characteristics (Kizilcec et al., 2017; Teng \& Huang, 2019; Wei, Chen, \& Adawu, 2014). The differences identified in this study include educational and professional background, topic familiarity, self-efficacy, reading skills, and personality traits. Although the finding of this study differs to some extent from those of Teng and Huang (2018), who researched secondary school students, it is consistent that topic familiarity is a factor that influences students' metacognitive strategies in writing either at secondary or tertiary level. See further explanation on how the informants implemented their metacognitive strategies in thesis writing during the pandemic.

Researching in a pandemic surely involves much effort. The pandemic was officially issued in Indonesia on March 11, 2020, when the informants started planning their thesis proposal and had to adjust the plan with the unpredictable emergence of the COVID-19 pandemic. At the planning stage, the findings revealed that identifying literature sources appeared to be a challenge. During lockdown and social distancing restriction, the campus was temporarily closed, and the informants ought to spend extra credits for internet access to get the sources. This condition added more financial burden as there some of the family member get laid off from work. The family economic condition contributes significantly to students' intention to complete the study on time during the pandemic (Rahardianto, 2020). While writing, they believed that the anxiety of working from home was a factor that hindered their productivity. The need for information sharing was not fully accommodated as they were worried about social contact (Baloran, 2020). The informants sought support from classmates and thesis supervisors through online communication media. At last, in the stage of evaluation and revision, the findings indicate that notwithstanding the low self-esteem, the students still worked hard to meet their thesis supervisors' satisfaction.

\section{Challenges and solutions in thesis writing during the pandemic}

Finally, the last substantive theories derived from the open-ended questionnaire and interview results interpreted that ineffective supervision system and time management, dual roles of the subjects' identities, heavy workload, network interruption, demotivation, procrastination habit, and imposter syndrome were the challenges during the thesis writing in the pandemic. Student-thesis supervisor interaction is a critical success factor in thesis writing (Karunaratne, 2018). Amid a pandemic, the success of the online supervision process relies on technological expertise and effective communication. Nevertheless, interrupted connection and hanging issues occurred, affecting time efficiency and decreasing the information clarity. The students still needed to clarify the messages, yet the response was not as fast as meeting in person with the supervisors. The lack of immediacy left the students hesitant about the quality of their works, and they eventually felt reluctant to proceed with the thesis writing due to uncertainty. This condition leads to procrastination habits and poor time management. The finding corroborates Butcher and Sieminski's (2006) study, as cited in Zaheer and Munir (2020), stating that face-to-face interaction is critical for motivation and self-efficacy. This finding would seem to extend our knowledge that imposter syndrome does not only arise from individuals distinguishing between their abilities and others' (Kelly, 2018) but also from comparing themselves skeptically in a different situation. In conclusion, the psychological aspects significantly affect the success of thesis writing. 
The last point to discuss is how the students overcome the barrier, generally speaking, our results showed that nearly all the students failed to do it as they could not finish the study on time. Interestingly, 1 out of 13 informants extraordinarily applied effective time management, completing the thesis writing on time. She is a working student, while the other 12 informants were full-time students. She is so determined and possesses a high level of self-discipline. The finding of this study seemed to affirm Zaheer and Munir's study (2020), stating that students' positive attitude plays the most crucial role in completing tasks no matter whether they hold single or dual roles.

\section{CONCLUSION}

Working on the thesis during the pandemic was a challenge in that it affected the success of thesis writing primarily for the students who worked from home. Regarding the problem formulation, the findings depict that among all steps of metacognitive strategies, the informants struggled the most at generating online strategies resulting in the master thesis completion delay. It is also confirmed that individual differences contribute substantially to varied metacognitive strategies used by EFL graduates during thesis writing. We could interpret the challenges from the findings that time management, consultation system, technological issues, and psychological factors are variables attributed to unaccomplished writing. The negative disruptive emotions such as lack of motivation, procrastination habits, and imposter syndrome impact the regulation of the informants' cognition. One downside factor regarding our study is that we could not provide as many solutions to tackle the problems during thesis writing in the pandemic because the informant who have finished the thesis writing limit the number. More studies with a larger sample size are needed. In addition, future studies may target experiments on creating an online university-accredited platform that could record the thesis progress accessible to the students, supervisors, and faculty management. It is valuable to encourage students to complete the thesis writing on time and raise the university's graduation rate.

\section{REFERENCES}

Almeatani, M., Alotaibi, H., Alasmari, E., Meccawy, M., \& Alghamdi, B. (2019). Thesis supervision mobile system for enhancing student-supervisor communication. International Journal of Interactive Mobile Technologies, 13(6), 4-14. https://doi.org/10.3991/ijim.v13io6.9533

Aucejo, E. M., French, J., Ugalde Araya, M. P., \& Zafar, B. (2020). The impact of COVID-19 on student experiences and expectations: Evidence from a survey. Journal of Public Economics, 191, 104271. https://doi.org/10.1016/j.jpubeco.2020.104271

Baloran, E. T. (2020). Knowledge, Attitudes, Anxiety, and Coping Strategies of Students during COVID-19 Pandemic. Journal of Loss and Trauma, 25(8), 635-642. https://doi.org/10.1080/15325024.2020.1769300

Cer, E. (2019). The Instruction of Writing Strategies: The Effect of the Metacognitive Strategy on the Writing Skills of Pupils in Secondary Education. SAGE Open, 9(2). https://doi.org/10.1177/2158244019842681

Farahian, M., \& Avarzamani, F. (2018). Metacognitive awareness of skilled and less-skilled EFL writers. Asian-Pacific Journal of Second and Foreign Language Education, 3(1). https://doi.org/10.1186/s40862-018-0052-4

Fitzgerald, J., \& Shanahan, T. (2000). Reading and writing relations and their development. Educational Psychologist, 35(1), 39-50. https://doi.org/10.1207/S15326985EP3501_5

Flower, L., \& Hayes, J. R. (1981). A Cognitive Process Theory of Writing. College Composition and Communication, 32(4), 365. https://doi.org/10.2307/356600

Goctu, R. (2017). Metacognitive Strategies in Academic Writing. Journal of Education in Black Sea Region, 2(2), 82-96. https://doi.org/10.31578/jebs.v2i2.44

Graham, S., Liu, X., Bartlett, B., Ng, C., Harris, K. R., Aitken, A., Barkel, A., Kavanaugh, C., \& Talukdar, J. (2018). Reading for Writing: A Meta-Analysis of the Impact of Reading Interventions on Writing. Review of Educational Research, 88(2), 243-284. https://doi.org/10.3102/0034654317746927

Hacker, D. J. (2009). Handbook of Metacognition in Education. In Handbook of Metacognition in 
Education. https://doi.org/10.4324/9780203876428

Handayani, F., \& Handayani, N. (2020). The Potential Of Online Writing Tools For Efl University Students During The Covid-19 Pandemic. JEE (Journal of English Education), 6(1), 9-18. https://doi.org/10.30606/jee.v6i1.406

Indrawati, B. (2020). Tantangan Dan Peluang Pendidikan Tinggi. Jurnal Kajian Ilmiah, 1(1), 3948.

Karunaratne, T. (2018). Blended supervision for thesis projects in higher education: A case study. Electronic Journal of E-Learning, 16(2), 79-90.

Kelly, D. (2018). The individual and social complexities of metacognition in education-based learning. May.

Lee, I., \& Mak, P. (2018). Metacognition and Metacognitive Instruction in Second Language Writing Classrooms. TESOL Quarterly, 52(4), 1085-1097. https://doi.org/10.1002/tesq.436

Lestari Setyowati, S. S.-A. A. E.-S. (2020). Learning from the Pandemic: Using Authentic Materials for Writing Cause-Effect Essay in Indonesian Context. International Journal of Languages Education, 8.3(8.3), 158-167. https://doi.org/10.29228/ijlet.45405

Maftoon, P., Birjandi, P., \& Farahian, M. (2014a). Investigating Iranian EFL learners' writing metacognitive awareness. International Journal of Research Studies in Education, 3(5). https://doi.org/10.5861/ijrse.2014.896

Maftoon, P., Birjandi, P., \& Farahian, M. (2014b). Investigating Iranian EFL learners' writing metacognitive awareness Investigating Iranian EFL learners ' writing metacognitive awareness. International Journal of Research Studies in Education ', October, 1-17. https://doi.org/10.5861/ijrse.2014.896

Mahmoudi, A. (2017). Effect of Planning on Iranian Intermediate EFL Learners' Mastery of Writing $\begin{array}{lllll}\text { Skill. Theory and Practice in Language Studies, } 7(3), & 219 .\end{array}$ https://doi.org/10.17507/tpls.0703.08

Mhunpiew, N. (2013). A supervisor's roles for successful thesis and dissertation. US-China Education Review, 3(2), 119-122. http://files.eric.ed.gov/fulltext/ED540484.pdf

Murtadho, F. (2021). Metacognitive and critical thinking practices in developing EFL students' argumentative writing skills. Indonesian Journal of Applied Linguistics, 10(3), 656-666. https://doi.org/10.17509/ijal.v10i3.31752

Ong, J., \& Zhang, L. J. (2013). Effects of the manipulation of cognitive processes on efl writers' text quality. TESOL Quarterly, 47(2), 375-398. https://doi.org/10.1002/tesq.55

Pitenoee, M. R., Modaberi, A., \& Ardestani, E. M. (2017). The Effect of Cognitive and Metacognitive Writing Strategies on Content of the Iranian Intermediate EFL Learners' Writing. Journal of Language Teaching and Research, 8(3), 594. https://doi.org/10.17507/jltr.0803.19

Qin, L., \& Zhang, L. J. (2019). English as a foreign language writers' meta cognitive strrategy knowledge of writing and their writing performance in multimedia environments. Journal of Writing Research, 12(2), 393-413.

Rahardianto, W. (2020). Intention to Graduate on Time During Covid-19 Pandemic . The Moderating Role of Degree Program . Intention to Graduate on Time During Covid-19 Pandemic . The Moderating Role of Degree Program . A Case Study in Student of IPMI International Business School.

Ramadhanti, D., Ghazali, A. S., Hasanah, M., \& Harsiati, T. (2019). Students' metacognitive weaknesses in academic writing: A preliminary research. International Journal of Emerging Technologies in Learning, 14(11), 41-57. https://doi.org/10.3991/IJET.V14I11.10213

Sala-Bubaré, A., \& Castelló, M. (2018). Writing regulation processes in higher education: a review of two decades of empirical research. Reading and Writing, 31(4), 757-777. https://doi.org/10.1007/s11145-017-9808-3

Salgado, A. (2015). The Style Of Thesis Supervision On Student Progress (Vol. 151, Issue 1).

Schraw, G., \& Dennison, R. S. (1994). Assessing metacognitive awareness. In Contemporary Educational Psychology (Vol. 19, Issue 4, pp. 460-475). https://doi.org/10.1006/ceps.1994.1033

Soberg, P. (2018). Reflective learning : Fostering motivation, metacognition, and autonomy, and raising language learning strategy awareness. $1-87$. https://minds.wisconsin.edu/handle/1793/78796

Styati, E. W., \& Irawati, L. (2020). The Effect of Graphic Organizers on ELT Students' Writing 
Quality. Indonesian Journal of EFL and Linguistics, 5(2), 279. https://doi.org/10.21462/ijefl.v5i2.283

Teng, F. (2019). The role of metacognitive knowledge and regulation in mediating university EFL learners' writing performance. Innovation in Language Learning and Teaching, 14(5), 436450. https://doi.org/10.1080/17501229.2019.1615493

Thi Nhat, H., Thi Lien, N., Thi Tinh, N., Vu Thu Hang, N., \& Thu Trang, N. (2018). The Development of Critical Thinking for Students in Vietnamese Schools: From Policies to Practices. American Journal of Educational Research, 6(5), 431-435. https://doi.org/10.12691/education-6-5-10

Tosuncuoglu, I., \& Kirmizi, Ö. (2019). A Review on Writing Metacognitive Awareness of Turkish Advanced Level EFL Learners. International Online Journal of Education and Teaching, 6(1), 136-149.

Wajdi, M. B. N., Iwan Kuswandi, Umar Al Faruq, Zulhijra, Z., Khairudin, K., \& Khoiriyah, K. (2020). Education Policy Overcome Coronavirus, A Study of Indonesians. EDUTEC: Journal of Education And Technology, 3(2), 96-106. https://doi.org/10.29062/edu.v3i2.42

Wei, J., Chen, J., \& Adawu, A. (2014). Teaching ESL beginners metacognitive writing strategies through multimedia software. CATESOL Journal, 26(1), 60-75.

Weil, L. G., Fleming, S. M., Dumontheil, I., Kilford, E. J., Weil, R. S., Rees, G., Dolan, R. J., \& Blakemore, S. J. (2013). The development of metacognitive ability in adolescence. Consciousness and Cognition, 22(1), 264-271. https://doi.org/10.1016/j.concog.2013.01.004

Wenden, A. L. (1998). Metacognitive knowledge and language learning. Applied Linguistics, 19(4), 515-537. https://doi.org/10.1093/applin/19.4.515

Xiao, Y. (2007). Applying metacognition in EFL writing instruction in China. Reflections on English Language Teaching, 6(1), 19-33. 